\title{
POLYMORPHISM OF MICROSATELLITE SEQUENCE WITHIN ABC TRANSPORTER GENES IN PHYTOPATHOGENIC FUNGUS, MAGNAPORTHE GRISEA
}

Lin Liu ${ }^{1}$, Chengyun $\mathrm{Li}^{1}{ }^{1}$, Jing Yang ${ }^{1}$, Jinbin $\mathrm{Li}^{2}$, Yuan $\mathrm{Su}^{1}$, Yunyue Wang $^{1}$, Yong Xie ${ }^{1}$, Youyong Zhu ${ }^{1}$

${ }^{1}$ Key Laboratory for Agricultural Biodiversity and Pest Management of China Education Ministry, Plant Protection College, Yunnan Agricultural University, Kunming, 650201, China

${ }^{2}$ Plant Protection Research Institute of Yunnan Academy of Agricultural Sciences, Kunming, 650205, China

* Corresponding author, Address: Chengyun Li, Key Laboratory for Agricultural Biodiversity and Pest Management of China Education Ministry, Yunnan Agricultural University, Hei Longtan, Kunming, 650201, P. R. China, Tel: +86-871-5227552, Fax: 86-871-5227552, Email: li.chengyun@gmail.com

Abstract: Thirteen polyporphic microsatellite markers suitable for population genetic structure analysis and $\mathrm{ABC}$ transporter and signal transduction coding genes variation measurement were developed for rice blast fungus, Magnaporthe grisea. Polymorphism was evaluated by using forty-six isolates collected from diverse geographical locations and rice varieties. Preliminary results indicated that each locus resolved multiple alleles ranging from two to ten. There results showed that these SSR-containing genes are also polymorphic in the natural population.

Keywords: Magnaporthe grisea, $\mathrm{ABC}$ transporter, microsatellite

\section{INTRODUCTION}

Rice blast disease, caused by Magnaporthe grisea, is the devastated disease of cultivated rice in most rice-growing regions worldwide. The

Liu, L., Li, C., Yang, J., Li, J., Su, Y., Wang, Y., Xie, Y. and Zhu, Y., 2008, in IFIP International Federation for Information Processing, Volume 258; Computer and Computing Technologies in Agriculture, Vol. 1; Daoliang Li; (Boston: Springer), pp. 553-558. 
fungus exhibits a high level of pathotype variation. Potential mechanisms contributing to this variation include mutation, migration, parasexual recombination or an as yet unobserved sexual stage in the field (Ou, 1985). Disease management strategies would greatly benefit from an increased understanding of the amount and distribution of genetic diversity in this pathogen. The completion of the fungus genome sequence project has made it possible to determine not only the total number of genes, but also the exact number of genes of a particular type and analysis their structure and function in details (Ou, 1985; Zeigler et al., 1997). As a consequence, we now know exactly how many regulatory gene are encoded by the blast fungus genome, and how many genes contain simple sequence repeats (SSRs) within protein coding regions. Trinucleotide repeats are clustered in regulatory genes in Saccaromyces cerevisiae (Young et al., 2000) and rice blast fungus (Li et al., 2005), but all these SSRs are structurally and functionally polymorphisms, are still unknown.

Microsatellites are founded in both eukaryotes and prokaryotes. It nonrandomly distributes either in expressed sequence tags (ESTs) and genes, including protein-coding, 3'-UTRs and 5'-UTRs, or in introns. The consequences of SSRs repeat-number changes are different in those regions of both prokaryotes and eukaryotes. For example, 14\% of protein-coding regions of all known proteins in eukaryotes was proved to containing repeated sequences, and it is three times higher abundance of repeats than in prokaryotes (Marcotte et al., 1998). Characterized with relatively rapid and inexpensive, microsatellites are favored for genetic research, it was not only applied to polymorphic resolve within species but also commonly used to identify specific chromosomal regions consistently across populations.

Genes involved in $\mathrm{ABC}$ transporters play a key role in development and pathogenicity of fungal pathogens. The ATP-binding cassette (ABC) superfamily of active transporters is composed of about 50 functionally diverse prokaryotic and eukaryotic transmembrane proteins (Higgins, 1992; Michaelis and Berkower, 1995). The ABC transporters not only carry a variety of substrates into or out of the cell, but also are involved in intracellular compartmental transport. These proteins utilize energy derived from the hydrolysis of ATP to transport the substrate across the membrane against a concentration gradient.

The previous work showed that microsatellite sequences, especially trinucleotide repeats are richness in protein kinase and $\mathrm{ABC}$ transporter coding genes of fungus (Keleher et al., 1992). The objective of this study was to determine the polymorphism of these microsatellite loci by PCR assay of loci among natural population in M. grisea. 


\section{MATIERIALS AND METHOD}

The DNA sequence, a database of known and predicted open reading frames (ORF) of eukaryotic $\mathrm{ABC}$ transporters were obtained from the Maganaporthe grisea genome database World Wide Web site: http://www.genome.wi.mit.edu/annotation/fungi/magnaporthe/ on July 14, 2005, and was made sure by Maganaporthe grisea genome database World Wide Web site: http://www.broad.mit.edu/annotation/genome/magnaporthe_ grisea/ on May 12, 2006. We used the program software tandem repeats finder (TRF) written by Benson (Benson, 1999) with the following options: minimum size $=15 \mathrm{bp}, 80 \%$ matches (namely number of matched bases between two repetitive elements is $80 \%$ ) and abundance was removed.

Polymorphic loci were detected by screening a subset of 46 isolates of M. grisea collected from different regions (including japonica, indica rice grown regions) and various rice varieties of Yunnan Province, China. The genomic DNA were extracted from mycelia using a simple extraction protocol (Sweigard et al., 1990). Primers were designed for DNA sequence with microsatellite motifs using PRIMER3 (Rozen and skaletsky, 2000) software and synthesized by Invitrongen Biotechnology Co. Ltd. Shanghai, China.

PCR amplifications were performed in $20 \mu \mathrm{L}$ volumes containing $1 \times$ PCR buffer (10 mM Tris- $\mathrm{HCl} \mathrm{pH} 8.5,50 \mathrm{mM} \mathrm{KCl}, 1.5 \mathrm{mM} \mathrm{MgCl}_{2}$, and $0.001 \%$ gelatin), $125 \mu \mathrm{M}$ each dNTP, 5 pmol of each primer, and $0.5 \mathrm{U}$ of Taq DNA polymerase (Sino-American Biotechnology Co., Beijing). Approximately $50 \mathrm{ng}$ of genomic DNA was used for each reaction. Amplification were performed in a Eppendoff PCR thermal Mastercycler with the cycling parameters; $2 \mathrm{~min}$ and $30 \mathrm{sec}$ at $94^{\circ} \mathrm{C}, 35$ cycles of $30 \mathrm{sec}$ at $94^{\circ} \mathrm{C}, 1 \mathrm{~min}$ at $55^{\circ} \mathrm{C}$ and $1 \mathrm{~min}$ at $72^{\circ} \mathrm{C}$ followed by a final extension for $10 \mathrm{~min}$ at $72^{\circ} \mathrm{C}$. In initial experiments, amplified fragments were visualized by electrophoreses in $1.5 \%$ agarose gels stained with ethidium bromide. Those loci appeared polymorphic were further examined by $8 \%$ polyacrylamide gel to determine the product size of the PCR product and number of alleles per locus. Fragment size of PCR products were estimated on Bio-Imaging System E5000.

\section{RESULTS AND DISCUSSION}

Thirteen of the fifteen polymorphic loci produced amplicons from a majority of 46 isolates, and displayed two to ten alleles (Table 1). Observed 


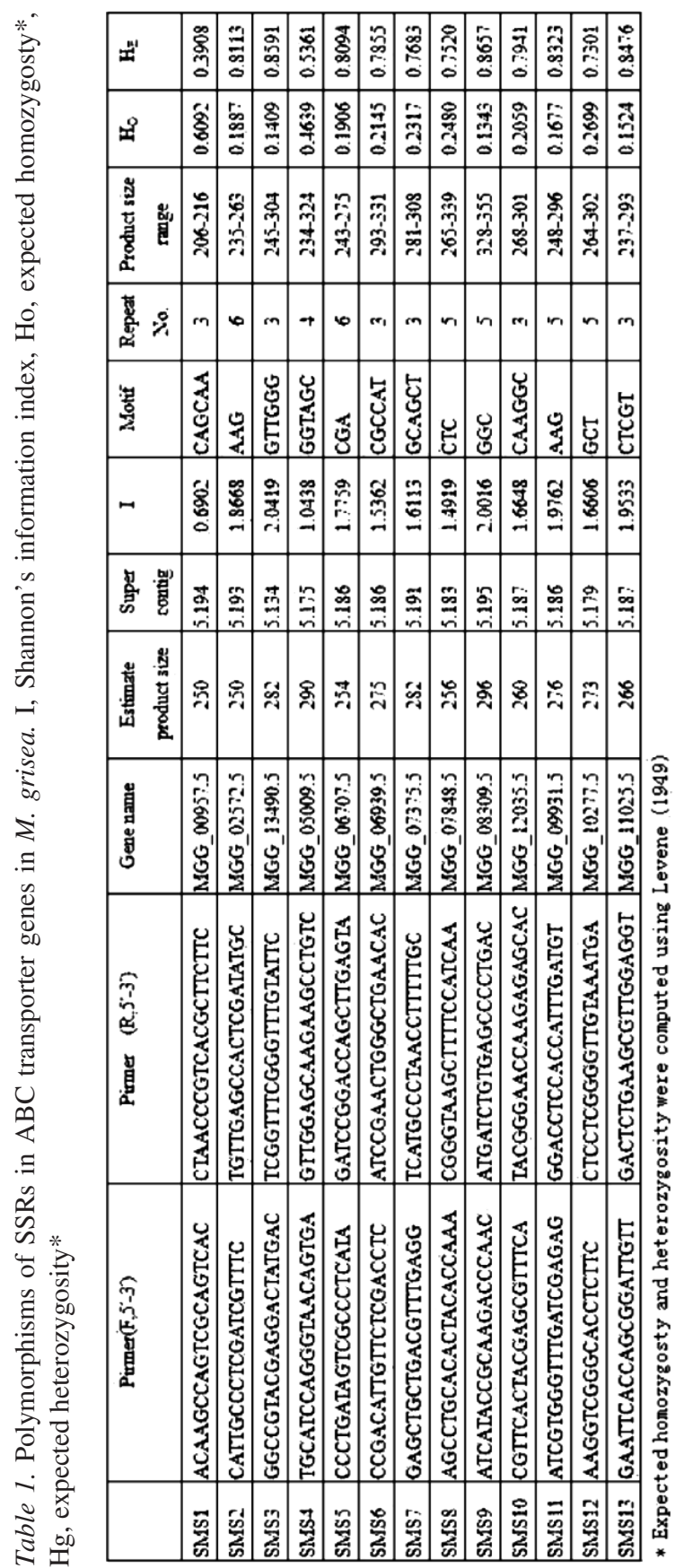


heterozygosity and expected heterozygosity values by software GENEPOP (V1.34), were shown in table 1. The results suggested that genes harbored these SSR sequence are also diversity in isolates used.

\section{CONCLUSIONS AND FUTURE WORKS}

The high degree of polymorphism in this set of microsatellite markers can be used to analysis of population structure and strain distribution in association with particular commodities and locations, as well as complemented for understanding function of regulatory genes in the fungus. With integration of such information into strategies of the functional genomics, it would facilitate SSR functions Study.

\section{ACKNOWLEDGEMENTS}

This work is supported by National Basic Research Program of China (2006CB100202), Education Ministry Foundation (307025) and Doctorial Foundation of Education Ministry of China (20050676001).

\section{REFERENCES}

Benson G. 1999, Tandem repeats finder: a program to analyze DNA sequences. Nucleic Acids Res 27, 573-580.

Cecconi F., Alvarez-Bolado G., Meyer B.I., Roth K.A., Gruss P. 1998, Apaf1 (CED-4 homolog) regulates programmed cell death in mammalian development, Cell 94, 727-737.

Dean Ralph A., Talbot Nlcholas J., Ebbole Danlel J. Ebbole, Mark L. Farman, Thomas K. Mltchell, Marc J. Orbach, Mlchael Thon, Resham Kulkarnl, Jin-Rong Xu, Huaqln Pan, Nlck D. Read, Yong-Hwan Lee, lgnazlo Carbone, Doug Brown, Yeon Yee Oh, Nlcole Donofrlo, Jun Seop Jeong, Darren M. Soanes, Slavlca Djonovlc, Elena Kolomlets, Cathryn Rehmeyer, Welxi Li, Michael Hardlng, Soonok Klm, Marc-Henrl Lebrun, Heidl Bohnert, Sean Coughlan, Jonathan Butler, Sarah Calvo, Li-Jun Ma, Robert Nicol, Seth Purcell, Chad Nusbaum, James E. Galagan \& Bruce W. Blrren 2005, The genome sequence of the rice blast fungus Magnaporthe grisea. Nature 434, 980-986.

Edward M. Marcotte, Matteo pellegrini, Todd O. Yeates and David Eisenberg 1998, A census of protein repeats, J. Mol. Biol. 293, 151-160.

Higgins C.F. 1992, ABC transporters: from microorganisms to man. Annu. Rev. Cell. Biol. 8, 67-113.

Keleher C.A., Redd M.J., Schultz J., Carlson M., Johnson A.D. 1992, Ssn6-Tup1 is a general repressor of transcription in yeast, Cell 68, 709-719.

Li Cheng-yun, Li Jinbin, Zhou Xiao-gang, Zhang Shao-song, Dong Ai-rong, Xu Ming-hui 2005, Frequency and Distribution of Microsatellite sequence in Open Reading Frames of Rice Blast Fungus, Magnaporthe grisea. Chinese J. Rice Science 19(2), 167-173, 2005. (in Chinese with English abstract). 
Michaelis S., Berkower C. 1995, Sequence comparison of yeast ATP-binding cassette proteins. Cold Spring Harbor Symp Quant Biol 60, 291-307.

Ou S.H. Rice diseases 1985, 2nd Edition. Commonwealth Mycological Institute, Kew, UK, 1985. 380.

Rozen S., Skaletsky H. 2000, Primer3 on the WWW for general users and for biologist programmers. Methods Mol. Biol. 132, 365-386.

Saxena K., Gaitatzes, C., Walsh, M.T., Eck, M., Neer, E.J., and Smith, T.F. 1996, Analysis of the physical properties and molecular modeling of Sec13: a WD repeat protein involved in vesicular traffic, Biochemistry 35, 15215-15221.

Stifani S., Blaumueller C.M., Redhead N.J., Hill R.E., Artavanis Tsakonas S. 1992, Human homologs of a Drosophila Enhancer of split gene product define a novel family of nuclear proteins [published erratum appears in Nat. Genet. Dec2(4), 119-127.

Sweigard, J.A., Orbach, M.J., Valent, B., Chumley, F.G. 1990, A miniprep procedure for isolating genomic DAN from Magnaporthe grisea, Fungal. Genet. Newslett 37, 4

Vaisman N., Tsouladze A., Robzyk K., Ben-Yehuda S., Kupiec M., Kassir Y. 1995 The role of Saccharomyces cerevisiae Cdc40p in DNA replication and mitotic spindle formation and/or maintenance, Mol. Gen. Genet 247, 123-136.

Young E.T., Sloan, J.S. and Riper K.V. 2000, Trinucleotide repeats are clustered in regulatory genes in Saccharomyces cerevisiae. Genetics 154, 1053-1068.

Zeigler, R.S., Scott, R.P., Leung, H., Bordeos, A. A., Kumar, J., and Nelson, R.J. 1997, Evidence of parasexual exchange of DNA in the rice blast fungus challenges its exclusive clonality. Phytopathology 87, 284-294. 